\title{
Thinking about the politics of inclusive development: towards a relational approach
}

Link to publication record in Manchester Research Explorer

\section{Citation for published version (APA):}

Hickey, S. (2013). Thinking about the politics of inclusive development: towards a relational approach. (ESID Working Paper Series; No. 1).

\section{Citing this paper}

Please note that where the full-text provided on Manchester Research Explorer is the Author Accepted Manuscript or Proof version this may differ from the final Published version. If citing, it is advised that you check and use the publisher's definitive version.

\section{General rights}

Copyright and moral rights for the publications made accessible in the Research Explorer are retained by the authors and/or other copyright owners and it is a condition of accessing publications that users recognise and abide by the legal requirements associated with these rights.

\section{Takedown policy}

If you believe that this document breaches copyright please refer to the University of Manchester's Takedown Procedures [http://man.ac.uk/04Y6Bo] or contact uml.scholarlycommunications@manchester.ac.uk providing relevant details, so we can investigate your claim.

\section{OPEN ACCESS}


Thinking about the politics of inclusive development: towards a relational approach.

Sam Hickey ${ }^{1}$

October, 2013

${ }^{1}$ IDPM, The University of Manchester

Email correspondence: sam.hickey@manchester.ac.uk

ISBN: 978-1-908749-22-2 


\begin{abstract}
Moving beyond the mantra that 'politics matters', a range of conceptual approaches have recently emerged within international development thinking that seek to capture the specific ways in which politics shapes development. This paper critically assesses whether these approaches, including work on 'limited access orders' and 'political settlements', can underpin research into how developmental forms of state capacity and elite commitment emerge and can be sustained. It suggests that these new approaches offer powerful insights into certain elements of this puzzle, particularly through a focus on the relational basis of elite behaviour and institutional performance. However, these approaches are also subject to serious limitations, and insights from broader and (in particular) more critical forms of political theory are also required in order to investigate how the politics of development is shaped by ideas as well as incentives, popular as well as elite forms of agency, transnational as well as national factors, and in dynamic as well as more structural ways. The paper proposes an initial conceptual framework that can be operationalized and tested within a programme of primary research to be established by the Effective States and Inclusive Development Research Centre.
\end{abstract}

Keywords: theory; politics; inclusive development; ideas; concepts; political settlements; limited access orders

\title{
Acknowledgements
}

This draft paper has benefited from very useful discussions with many people, and particular thanks are due to Adrian Leftwich, Diana Mitlin, Laura Routley, Kunal Sen and Michael Walton for incisive comments on various drafts. Thanks also to participants at various conferences and seminars where all or parts of this paper have been presented, including York, Canberra, Maastricht and the Open University. 


\section{Introduction}

'What kinds of politics can help to secure inclusive development and how can these be promoted?'

The Effective States and Inclusive Development Research Centre (ESID) has been established to address the over-arching research question detailed above. More specifically, ESID is concerned with identifying the particular conditions within which states gain the capacity and elites gain the commitment to deliver development. This focus responds to the now general acceptance that state capacity and elite commitment are both critical to securing inclusive development outcomes. High levels of state capacity have been a central feature in all successful cases of long-run development witnessed in the post-World War II era, whether in terms of growth (e.g. Evans, 1995; Leftwich, 1995; Vu, 2007; World Bank, 2008), social provisioning (Leftwich, 2008; Walton, 2010) or broader forms of democratic development involving rights and redistribution (Sandbrook et al., 2007). However, and given that states can be highly capable without necessarily being committed to development, the commitment of political elites to delivering development has also proved critical (Booth, 2011; Hossain and Moore, 2001; Leftwich, 1995; Vu, 2007).

Despite this consensus, there is far less agreement concerning the specific types and levels of capacity and commitment that matter for delivering different forms of development. Nor do we have a clear understanding of the particular conditions under which these forms of capacity and commitment emerge and can be sustained. This paper seeks to establish a conceptual basis for exploring the underlying conditions that shape the emergence and maintenance of developmental forms of capacity and commitment. It seeks to achieve this by first defining the key terms being used here and then critically assessing the potential of new conceptual approaches to politics and development to address this question. In particular, the paper offers a critical analysis of the extent to which the 'political settlements' and 'limited access orders' approaches can usefully underpin investigations into state capacity and elite commitment. It argues that such approaches offer powerful but limited insights into this problem and proposes an 'adapted political settlements' approach that draws in important insights from the broader realms of political theory, and particularly from more critical approaches.

Some definitional questions first. Our focus on 'inclusive development', involves at least two important moves. The first, and familiar move, is to go beyond a narrow understanding of development as a primarily economic process to one with an integral focus on the achievement of equity and the rights of citizenship. ${ }^{1}$ This is important not just in ethical terms but also because comparative historical evidence

\footnotetext{
${ }^{1}$ ESID has initially defined inclusive development as occurring when social and material benefits are equitably distributed across divides within societies (across income groups, genders, ethnicities, regions, religious groups and others). These benefits necessarily comprise not only economic and material gains but enhanced wellbeing and capabilities as well as social and political empowerment being widely experienced.
} 
suggests that the forms of politics that have underpinned inclusive forms of development (e.g. Evans 2010; Sandbrook et al., 2007; Walton 2010), differ in significant respects from those associated with economic growth (e.g. World Bank, 2008). ${ }^{2}$ The second move is to shift the focus beyond 'poverty' and 'the poor'. As argued elsewhere (Hickey, 2008), a discourse on poverty can make it difficult to think politically and may distract from a focus on achieving the fuller goal of social justice implied by the term 'inclusive development'. ${ }^{3}$ More instrumentally, a focus on inclusion responds to evidence that there may be greater political support for interventions that include non-poor as well as poor groups (e.g. Nelson, 2003), both in terms of better-off groups being more adept at attracting public goods provision and at maintaining a better quality of service delivery. The intention here then is to develop a more encompassing and relational view of development that problematises the workings of societies rather than the characteristics of particular groups and involves thinking in broader terms around how to achieve social justice, towards which poverty reduction is an essential but insufficient step.

In broad terms, we follow Adrian Leftwich's (2004) definition of politics as "all the processes of conflict, co-operation and negotiation on taking decisions about how resources are to be owned, used, produced and distributed", although for reasons explained later in the paper we consider the struggle over ideas (as well as resources) to be a fundamental and significant element of politics. In terms of our specific focus on capacity and commitment, state capacity refers here to "the ability of states to apply and implement policy choices within the territorial boundaries they claim to govern", and comprises three distinct, but interrelated dimensions: the state's embeddedness with non-state actors; the organizational competence of state agencies; and the territorial reach of state institutions (vom Hau, 2012). This approach goes beyond standard Weberian approaches and situates the state as firmly embedded within the broader economy and society (Evans, 1995; IDS, 2010), a central point to which we return below. Political commitment is a trickier concept to define. In a narrow sense, one approach is to simply define it as "the extent of committed support among key decision makers for a particular policy solution to a particular problem" (Post et al., 2010: 569). However, this policy-focused approach needs to be located in the broader context within which these key decision-makers operate, particularly in terms of their relationships to other elites. Here we define political elites as those "who have the organized capacity to make real political trouble" (Burton and Higley, 2001), and include those holding valued assets (e.g.

\footnotetext{
${ }^{2}$ The notion that 'inclusion' is uniformly 'good thing' is a misconception that a good deal of critical thinking on poverty analysis and social justice has sought to problematise and move beyond, not least because of the disempowering effects for weaker groups of being included on adverse terms in dominant political, economic and social orders (e.g. Jackson, 1999, Hickey and du Toit, 2007). The relational approach adopted here can be seen as an effort to avoid such simplistic readings of inclusion.

${ }^{3}$ For example, people rarely self-identify or organise themselves as 'the poor', which makes it difficult to appreciate popular agency through a poverty lens. Most poverty analysis relies on an analytical separation of the poor from the rest of society that tends to become moralised (Rothstein, 2002), often in ways that cast responsibility for both poverty and poverty reduction on the poor themselves and to therefore undermine the case for elites supporting large-scale public action.
} 
capitalists); those holding the power of adjudication over the distribution, allocation and regulation of property rights and use of property more broadly; those who possess authority to bargain on behalf of organised social groupings (di John and Putzel, 2009: 15); and those who play a role in establishing dominant ideas (e.g. public intellectuals, media owners). Importantly, these definitions draw attention to the role of elites at local as well as national levels, with the local often providing the key space within which development is actually delivered and where the ordinary subjects of development are most likely to interact with elites (Chatterjee, 2004). Having established some basic definitions, the next section discusses the potential of new conceptual approaches to politics and development to underpin research into the politics of how state capacity and elite commitment emerge and can be sustained.

\section{The mainstreaming of politics and political analysis within international development}

The use of political analysis within international development has come a long way over the past two decades, from largely marginal calls to 'bring politics back in' to a position whereby politics can claim to be 'in command' of the development agenda (cf. Leftwich, 1995, 2005). Throughout the 1990s and for much of the early 2000s, most mainstream research into the politics of development was located within the good governance agenda and underpinned by insights from new institutional economics. For critics, this conceptual focus on 'the rules of the game' only ever offered a limited and often technocratic understanding of how politics shaped development (Harris et al., 1997). Elsewhere, a focus on politics was viewed as something that could be bolted-on to existing frameworks of analysis, such as political capabilities and political capital (Hickey, 2009), rather than inspiring a more thoroughgoing reform in our understandings of how both development and problems of under-development emerge. This shift now appears to have occurred, with most major analyses of long-run development to emerge in the past few years placing politics at the heart of the story (Acemoglu and Robinson, 2012; Fukuyama, 2011; Khan, 2010; North et al., 2009). As suggested none too subtly by James Robinson in his review of Douglass North et al.'s influential (2009) study on Violence and Social Orders, 'It's the politics stupid'.

The major shift that seems to have occurred within mainstream analyses of politics and development is from a new institutionalist perspective towards a realisation that what lies behind the emergence and functioning of institutions is the complex world of politics and power relations. This shift is made particularly explicit by proponents of political settlements analysis, who claim that their historical political economy approach "offer(s) a more robust explanation of institutional change and development than new institutional economics" (di John and Putzel, 2009: 6). There is a particular focus here on the role of inter-elite relationships as a causal factor that underpins the emergence of stability and functioning institutions. For North et al. (2009) "political and economic development result from creating more sophisticated and durable 
institutions to structure elite relations within the dominant coalition"; as such, the differences between developed and developing countries is attributable to "the pattern of social relationships" in each, but particularly within the elite. This move from institutions to politics and power relations marks a potentially significant ontological shift within mainstream analyses of governance and development. As will become clear, we see the move towards a relational reading of the politics of development - as opposed to more institutional or materialist understandings of how politics plays out - as being a significant shift and one that we wish to articulate further. It is a move that chimes closely with other recent advances in politics and development thinking, including within the developmental states literature and the recent revival of relational approaches to understanding state capacity (Evans, 2010; vom Hau, 2012; $\mathrm{Vu}, 2007$ ) and research showing how broader state-society relations are critical to shaping the politics of development (IDS, 2010; Sandbrook et al., 2007; Walton, 2010).

Importantly, many of these insights have been apparent within forms of political theory that mainstream development analysis has failed to incorporate into its intellectual frame. The understanding that institutions emerge and are shaped by processes of conflict is a central feature of much of the political science literature (e.g. Knight, 1992), ${ }^{4}$ and particularly within more critical forms of political theory which have long viewed the state as a sphere within which broader social struggles take place and become articulated (e.g. Jessop, 1982, 2007). This focus is also a feature of recent scholarship on the state in Africa, such as Hagmann and Peclard's (2010) work on 'negotiated statehood'. The question for current research programmes on the politics of development, then, is to devise a coherent way of operationalising the core insights of these approaches in ways that enable a clearer sense of which forms of politics matter in shaping inclusive development. The remainder of this section establishes the basis for this by critically evaluating the major claims made within recent developments in mainstream thinking before turning to contributions from more critical theoretical positions.

\subsection{The political settlements approach to effective states and inclusive development}

The notion that institutional functioning and the underlying conditions for development are established first and foremost by the character of intra-elite relations forms the central concern of both Khan's work on 'political settlements' (2010) and North et al.'s (2009) idea of 'limited access orders' and how they might become 'open access orders'. ${ }^{5}$ Driven from a political economy perspective, the political settlements approach offers a strong focus on the role that capitalism and political organisations play in shaping development processes and outcomes, whilst

\footnotetext{
${ }^{4}$ I am grateful to Adrian Leftwich for drawing this work to my attention.

${ }^{5}$ It also closely informs the shift by Acemoglu and Robinson away from their view of elites as a homogenous group (e.g. 2006), in favour of a more disaggregated approach that views conflicts and bargains between elites as critical (2012).
} 
the historical institutionalism of North et al. centres more clearly on processes of institutional functioning and development. Despite important intellectual differences between the two approaches, ${ }^{6}$ they derive from similar ontological priors, particularly concerning their shared rational-actor perspective on political behaviour, which both enables their merger into a broader frame of analysis and also (as argued below) limits their view of certain key features of the politics of development. The growing influence of these new approaches within mainstream development agencies ${ }^{7}$ further highlights the need to subject them to critical evaluation.

\subsection{Political settlements: from stability to development}

The 'political settlement' refers to the balance or distribution of power between contending social groups and social classes, on which any state is based." (di John and Putzel, 2009: 4). Arrived at through a process of struggle and bargaining between elite groups, this settlement establishes the basis for institutional arrangements to take shape. Critically, institutions must be arranged to distribute enough resources to powerful organised groups in society, otherwise "these groups will strive through different means including conflict to change institutions till they are satisfied or they give up" (Khan, 2010: 4). This resonates with other recent accounts of how conflict emerges in relation to inter-elite relations and the character of ruling coalitions (e.g. Bates, 2008; Lindemann, 2008), and also North et al.'s explanation that social order can only exist once elites have reached an agreement amongst

\footnotetext{
${ }^{6}$ See Khan $(1995,2010)$ and di John and Putzel (2009: 8-10) for lengthy treatments of the differences between their approach and that of new institutionalism. For example, the latter authors place themselves: "In the long line of thinking in historical political economy, beginning with Marx" within which "analysing the balance of power between contending groups and classes has been central in exploring the formation and change of institutions such as the process of democratisation (Moore, 1966), the transition from feudalism to capitalism (Brenner, 1976), the effectiveness with which industrial policy is implemented (Khan, 1995; Kohli, 2004), and the closely related effort of historical institutionalists to explain the varied routes to capitalist transformation (Hall and Soskice, 2001)" (di John and Puzel, 2009: 4). The historical political economy approach draws explicit attention to capitalism and its effects on politics, as with Khan's (2010) claim that it is the size of the productive economy which effectively dictates the clientelist character of politics in developing countries, and that political settlements can be divided between those that are 'capitalist' and those that are 'clientelist'. Historical institutionalists, meanwhile, offer little analysis of capitalism itself other than as an outcome of elite bargaining around institutions such as property rights. They also tend to place a strong emphasis on how political settlements leads to the emergence of democratic institutional forms (North et al., 2009; also Higley and Gunther, 1992), whereas historical political economy thinkers appear to be more agnostic regarding which forms of politics might emerge. A related difference here, as noted by Bates (2010), is that historical institutionalists, such as North et al., focus on particular types of democratic institution (e.g. interest groups) rather than others (e.g. the role played by political parties and leaders) in achieving doorstep conditions and transitions beyond these. Historical political economy work tends to accord a much stronger role for this type of political organisation, not in terms of establishing democracy per se, but as key forces that can shape and reshape the character of political settlements and (accordingly) the institutional arrangements and patterns of resource distribution (di John and Putzel, 2009:12; Khan, 2010).

7 "Development practitioners are increasingly coming to the conclusion that political settlements directly affect the prospects for economic growth and poverty reduction, quality of services to the poor, and the level of violent conflict." (Parks and Cole, 2010: viii).
} 
themselves over the centralisation of violence and the operation of institutional constraints around a limited set of property rights.

The nature of the deals made by elites in turn shapes the character of the institutions that emerge to govern society. Once basic social order has been achieved, "the distribution of power becomes embedded in institutional arrangements that sustain it", most of which are informal in developing countries; these "...informal institutions both reflect but also ultimately sustain the distribution of power by creating supportive benefits for powerful groups." (Khan, 2010: 8). North et al. (2009) similarly argue that informal institutions rather than impersonal organisations predominate in most limited access orders because of the personalised nature of the 'deals' made between elites around the form and functioning of institutions. It is this interplay between elite power relations and institutions that helps define the essentially clientelistic and rentseeking character of political settlements and limited access orders in most developing countries, and which closely shapes their influence over development. For Khan (2010), the political economy of developing countries is also influential here in that the limited size and scope of the formal productive economy further ensures that informal arrangements dominate as governments lack the tax-base required to allocate resources to powerful groups other than through off-budgetary processes.

Taken together, these approaches suggest two main and inter-related transmission mechanisms through which political settlements and limited access orders shape developmental forms of state capacity and elite commitment. The first flows from the stability of institutional arrangements, the second from the nature of ruling coalitions. Political stability and order is critical not only for the simple reason that it allows institutions to function but also because stability enables elites to engage in the type of long-term thinking and planning required for growth to emerge (Kelsall et al., 2010). ${ }^{8}$ Where elites are constantly struggling to assert the legitimacy of a prevailing order, the incentives are to undertake short-termist measures designed to maintain order and keep the regime in power. In a context of personalised deals between elites, this involves both creating rent-seeking possibilities for potentially troublesome elites and securing their support for 'limited access' institutional arrangements that can offer help offer greater returns than they could attain through violent means (North et al., 2009). ${ }^{9}$

A more distinctive contribution concerns the role played by coalitions in shaping state capacity and elite commitment. In terms of state capacity, political settlements

\footnotetext{
${ }^{8}$ The resolution of conflict, particularly in ways that offer the emerging ruling coalition the legitimacy to make difficult decisions and the space to do so without significant opposition, is generally more possible under conditions of elite polarisation rather than elite compromise (see Vu, 2005).

${ }^{9}$ This dynamic extends from maintaining order to maintaining a specific ruling coalition in place, whereby political settlements characterised by competitive forms of clientelism, within which elites are frequently in danger of being displaced from power in contexts where holding political power is critical to accessing rents (as in Bangladesh and Ghana), will likely influence elites towards the short-term and factional distribution of goods to political supporters to maintain regime survival (Levy, 2012; also Whitfield and Therkildsen, 2011).
} 
analysis suggests that state organisations are unable to act effectively unless the nature of the political settlement within which they are located permits them to do so. The political coalitions at the heart of political settlements are thus historically and logically prior to the emergence of state capacity: responding to her own question of “...how can we account for variation in state building?", Poteete's (2009: 455-6) response is that "Behind policies, institutions, and state building lie political coalitions". ${ }^{10}$ The capacity of the state to act, and whether or not effective state institutions get built and are allowed to function, is therefore determined by the character of the players, coalitions and agreements made around the operation of power - not about formal Weberian forms of state capacity per se. So, it would be feasible to imagine a state with high levels of bureaucratic capacity and infrastructural power, but which was prevented from acting in certain policy domains due to the lack of an agreement between dominant groups. From this perspective, then, state capacity is endogenous to the relations that underpin the political settlement.

Two dimensions of coalitional politics within 'clientelist' political settlements can help explain differing levels of capacity and commitment to delivering development: the organisation of the ruling coalition and the technological capabilities of productive entrepreneurs in that society and their relationship of power with the ruling coalition. With regards the first, Khan (2010: 8-9) argues that:

"The greater the power of horizontally excluded factions, the greater the vulnerability of the ruling coalition. This reduces its time horizon which affects the types of economic strategies it will be willing to support through formal and informal institutions". ${ }^{11}$

Some pursue this line of thinking to argue that the inclusivity of the ruling coalition is critical, as in Poteete's (2009) suggestion that the inclusivity and stability of the ruling coalition in Botswana has directly shaped the capacity and commitment of elites to maintain good levels of economic growth despite the danger of the resource curse:

"Politicians with narrow and unstable coalitions see rentier politics as an attractive coalition building strategy; their responses to this political problem hinder state building... Politicians with broader and more stable coalitions are less likely to turn to rentier politics to bolster political

\footnotetext{
${ }^{10}$ Also see van Wyck's study of political and economic settlements South Africa, whereby "The nature of the pact and its subsequent coalition proscribed and restricted the capacity of the new government vis-a-vis economic and development policy." (2009: 16).

${ }^{11}$ Part of Khan's analysis of the growth-stability trade-off refers to cases where African rulers have been wary of promoting capitalism, often due to a fear of the political costs of the empowerment that this would have offered to non-African capitalists who have often been amongst the most productive entrepreneurs. Amin's expulsion of Asian Ugandans is only the most visible example of a more general tendency.
} 
support, in part because they are more apt to believe that they will reap the benefits from investments in state building" (544). ${ }^{12}$

However, Khan's argument is arguably more subtle than this call for 'inclusive' political settlements. What seems to matter in his account is the relative power of the excluded factions. Where dissonant groups are weak and can be excluded from a ruling coalition without significant danger of order being threatened, this may help support a degree of cohesiveness within the ruling coalition that is beneficial to growth. This argument finds further support in some recent work on the types of intraelite relations that underpin developmental states, including Kohli's (2004) work on cohesive capitalism and Vu's (2007) analyses of developmental states in East Asia, which includes cases where 'elite polarisation' has occurred to positive developmental effects. $\mathrm{Vu}$ argues that a mixture of elite polarisation and mass suppression provided the structural basis for developmental states to emerge in these cases, supporting the broader argument that 'inclusive' political settlements may be less economically productive and offer less social provisioning than more exclusive ones. ${ }^{13}$ Even 'inclusive elite coalitions', as in the case of Botswana (Poteete, 2009; Subudubudu with Molutsi, 2009), have imposed structural inequality and destitution on some marginal groups, not by accident but as a direct result of pursuing the interests of certain elites within the ruling coalition (Good, 1999). It might even be that political settlements can become more exclusive and even predatory as long as they are providing security and economic development, as some argue is occurring in Cambodia (Parks and Cole, 2010: 9).

However, this issue may again hinge on what is meant by the term 'inclusive'. In discussions of political stability the tendency has been to emphasise the ethnoregional aspects of inclusivity, as with Lindemann's (2008) argument that the presence of an ethnically inclusive coalition in Zambia largely explains the absence of civil war onset in the post-independence period, which is the reverse of what he finds for conflict-affected Uganda over the same period. If development rather than peace forms the focus, however, then the two countries diverge in the opposite direction, suggesting that the proper space within which to consider the relational basis of developmental state capacity lies not with ethnicity but class/socio-economic groupings. For example, Rakner (2003) suggests that what really undermined both

\footnotetext{
${ }^{12}$ This is also the line taken in Sandbrook et al.'s (2007) study of how social democracy has emerged in the global periphery, which argues that "All ethnic or communal groups must be represented in the political and bureaucratic elite to ensure that all groups are, and feel, represented" (24).

${ }^{13}$ Vu's study of state formation and developmentalism in South Korea and Indonesia preempted much recent research on political settlements. His theoretical framework (2007: 2931 ) identifies intra-elite and elite-mass interrelations as critical to developmental statism. Elitemass relations can be characterised in terms of mass incorporation or mass suppression, while intraelite relations involve more complex patterns, including elite unity versus elite fragmentation, and elite compromise verse elite polarisation "Elite unity is when one single group predominates, whereas elite fragmentation is when elites break into many small factions without any dominant group. When the number of groups is relatively small (but more than one) and they are roughly equal in strength, their alignment patterns may express in two other forms-elite compromise and elite polarization" (Vu, 2007: 29).
} 
political and economic development in Zambia between 1990 and 2000 was a particular set of liberal economic and political reforms that systematically broke the organisational power of key economic interest groups in society (business, unions, agricultural cooperatives) and also their relationships with the state.

The second aspect of ruling coalitions within political settlements which Khan suggests shapes capacity and commitment is the need within ruling coalitions to maintain certain types of relationships both horizontally (with other elite factions) and vertically (with organised social groupings) in order to preserve regime stability and survival will create strong incentives to act in particular ways. For Khan (2010: 64), "The relative power of productive interests and their technological and entrepreneurial capabilities can determine the incentives and opportunities of ruling coalitions to pursue particular institutional paths". This focus has strong echoes of recent work on state-business relations (e.g. Sen and te Velde, 2009) and of earlier work on the 'embedded autonomy' of developmental states (Evans, 1995; Routley, 2012; vom Hau, 2012). An important aspect concerns the issue of how such relationships can remain productive and avoid falling into the forms of collusion and crony capitalism that have been strongly associated with economic crises and stagnation. Khan draws attention to whether patron-client politics tend to be predatory as opposed to productive in particular contexts. Taking this forward, the work of the Africa Power and Politics Programme has suggested that, even within clientelistic political settlements, the presence of a political leadership with long-term time horizons, in alliance with centralised control over rent-seeking, can enable patrimonial settlements to be developmental (Kelsall et al., 2010). Where the tendency is towards decentralised rent-seeking and short-term exigencies the political settlement is likely to be predatory and unproductive, whereas the centralisation of rent-seeking in pursuit of a long-term vision can, for a time at least, offer productive possibilities in the form of 'developmental patrimonialism'. ${ }^{14}$

What has yet to be explored in political settlements research, which has dealt primarily with economic growth and productivity (Khan, Kelsall, Whitfield), is whether the coalitional dynamics required to underpin sustained economic growth are similar to those associated with high levels of capacity and commitment to delivering social goods. Aside from vague assertions that elites will extend benefits to non-elite groups once they are satisfied with the division of spoils amongst themselves (Khan, 2010; North et al., 2009), or when elites perceive it to be essential for regime survival (Bates, 2005; Whitfield and Therkildsen, 2011), there remains a gap in the literature concerning the role of political settlements in shaping the politics of social provisioning.

\footnotetext{
${ }^{14}$ Although this particular concept is a problematic one, the point that patronage and other forms of informal politics may play a productive role particularly at certain stages of development is an important one.
} 


\subsection{Summary}

A political settlements perspective offers some powerful insights regarding the emergence of developmental forms of capacity and commitment, many of which resonate with other recent work on the politics of development. In particular, the idea that "The overall causality runs from conflicts to coalitions to state capacity" (vom Hau, 2012: 11) is increasingly popular within studies of state capacity. Importantly, however, this relational perspective has arguably been developed and applied more persuasively within the comparative political science literature than is managed in the work of institutional economists, and is also contested in these broader realms too. In terms of the former, Slater's (2010) work on South-East Asia identifies the nature of elite alignments, and particularly the extent and strength of the 'protection pacts' that state elites are able to forge, as central to explaining how state capacity develops. For Kurtz (2009: 480), state administrative capacity is likely to develop "where two conditions obtain at the initiation of the process of state building - the absence of labor-repressive agriculture and exclusionary but collective elite political dominance":

"The former condition makes possible the centralization of authority and revenue extraction essential if state building is to proceed, while the latter renders it politically viable by ensuring that fundamental elite interests are not harmed in the process and that the collective benefits (and short-term rents) that development entails are well distributed among the upper classes". ${ }^{15}$

This work drives from a 'comparative social institutionalist' perspective rather than the narrower rational choice or historical institutionalism of Khan and North, and contributes deeper and fuller insights into the links between coalitions and state capacity by virtue of their broader understanding of the political economy of social change. Importantly, work in this tradition does not always accord a priori status to the underlying relations of power vis-à-vis institution building, but rather approaches this as something of a chicken-and-egg type situation. For example, Sandbrook et al. (2007) argue that, in addition to capitalist development, state formation is one of the key underlying conditions that must be in place before a social contract can be forged, such that, "A relatively coherent and effective state with some autonomy from dominant classes must emerge, for social-democratic regimes require states that can negotiate equitable social pacts, guide market forces, and administer social programmes" (30-31). Walton's (2010) analysis of the politics of long-run human

\footnotetext{
${ }^{15}$ Kurtz's (2009: 81) argument that "Rather infelicitously, it is also most probable where nonelite groups (workers, the middle classes, peasants) are excluded from effective political participation" chimes with some other work on developmental states (e.g. Vu, 2007) but stands in contrast to the work of Sandbrook et al. (2007) who argue that a shift in the agrarian class system which allows small-holder groups more influence over state functionaries is a typical feature of more social democratic development trajectories. 'Collective elite dominance' here refers to a situation whereby elites have clear predominance over popular classes and where "elite actors of all major factions are effectively incorporated in the institutions of governance in ways that ensure that no faction can easily become permanently dominant - and thus exclude all others from the on-going (collective and private) benefits of central governmental activity" (Kurtz, 2009: 481).
} 
development also accords a prior role to the development of state (and business) capacities, noting that these need to have reached a certain level before social contracts can be reached that then enable the institutions of capitalism and social provisioning to emerge.

In terms of elite commitment, political settlements research is aligned with recent research into the politics of development (IDS, 2010) in framing this question primarily in terms of incentives, whereby the underlying distribution of power generates incentives that shape elite behaviour. Again, this approach is both matched and trumped in more comparative accounts within political theory, as with Kurtz's (2009) findings that where the political settlement is reasonably stable and the ruling coalition incorporates all major factions with holding power then the conditions are in place for elites to adopt a longer-term horizon to institution-building and the distribution of public goods. ${ }^{16}$ However, Kurtz also stresses that the nature of political competition also matters here:

"Such cooperation is most likely where political competition takes on an iterated character, rather than embodying a zero-sum struggle for immediate dominance; when the former occurs, time horizons can lengthen and cooperation around public goods investment can occur" (Kurtz, 2009: 481).

Again, ontological priors are significant here. Work from a political settlements (or limited access orders) perspective understands elite commitment from a perspective of 'instrumental rationality', whereby the emergence of leaders with long-term vision derives not so much from ideological concerns or a sense of patriotic duty as from the incentives established by the nature of the political settlement. This ignores insights from other variants of thinking around rationality (Weber etc...), and particularly sociological forms of institutionalism which place a stronger emphasis on the role of 'values' in shaping elite behaviour. A political settlements perspective on elite commitment also suffers by comparison to other more multi-levelled approaches which (a) move beyond an elitist frame of analysis to show how popular uprisings, or at least the threat of them, can also shift elite commitment towards more popular concerns (e.g. Slater, 2010; also Henley, 2012) and (b) treat elites as transnational and not merely national actors, who are subject to influence by incentives and ideas that operate at more global levels. These problems are emblematic of wider failings within politics and development research that require recourse to alternative forms of political theory. The next section elaborates these problems more fully and suggests where future research into the politics of development can look for guidance in moving forward.

\footnotetext{
${ }^{16}$ Where the ruling coalition is more fragmented or less cohesive then short-termism is more likely to prevail, and where it is exclusive and particularistic the suggestion is elites will act in favour of certain interests over others, namely of those groups who are required to sustain a particular political settlement.
} 


\section{Beyond the new mainstream of politics and development analysis}

Political settlements thinking marks an important advance within the mainstream field of politics and development research, primarily through its focus on the role of politics and power relations vis-à-vis new institutionalist approaches. However, this emerging perspective is drawing increasing levels of disquiet from some quarters, in part because of the problem identified above whereby its underlying ontology can offer only a partial reading of politics. For Hudson and Leftwich (2013), many of the new approaches offer an essentially economistic version of political analysis grafted onto an old institutionalist frame. A key problem here is the failure to focus on the essentially dynamic and agential aspects of politics - or what Adrian Leftwich termed 'the games played within the rules of the game' - for which alternative understandings of politics and power are required. We concur with this critique and furthermore argue that the new mainstream tends to privilege the role of elite actors, understood from a limited rational-actor perspective, and to operate within a narrow frame of methodological nationalism. It is thus unable to capture the broader range of processes and factors that shape the politics of development, particularly in terms of the role of ideas, the agency of subordinate groups and the influence of transnational level factors.

The paper also goes further in terms of identifying the realms of political theory required to help capture these features, and argues that the most thoroughgoing treatment of politics as a relational phenomenon that is infused with struggles over power can be found within critical theory. In broad terms, this starts with Mouffe's (1993) call for political theory limited by liberal sensibilities to move beyond 'politics' to capture the 'political'. Politics here constitutes "the ensemble of practices, discourses and institutions that seek to establish a sense of social order and organization", while the political constitutes "the antagonistic dimension that is inherent in human societies and which is located within the struggles of diverse social groups for power and resources" (Mouffe, 1995, cited in Corbridge et al., 2005: 257). Whereas mainstream thinking around the politics of development has tended to focus on narrower, institutional forms of politics (Hickey, 2009), work within the critical tradition has long-recognised the importance of the political and how this shapes the functioning of institutions. For example, Jessop's work on the strategic-relational character of statehood draws on Marx, Gramsci and Poulantzas to define "state power is a complex social relation that reflects the changing balance of social forces in a determinate conjuncture" (Jessop, 1982, cited in Jessop, 2007: 28). In his 2007 work on State Power Jessop develops this insight to explore,

"...the conditions, if any, under which economic and political structures and processes can be coordinated strategically by a power bloc (comprising dominant class fractions and political elites) to guide economic and political development. These are important questions from 
a strategic-relational viewpoint and lend themselves to a strategicrelational inquiry" (2007: 25). ${ }^{17}$

The other relevant field to draw from in constructing a relational approach to the politics of development is within African studies, wherein the state has recently been repositioned as a 'negotiated' and deeply embedded social phenomenon (e.g. Hagmann and Peclard, 2010; Lund, 2006). For Hagmann and Peclard (2010: 552), "the state is the product of complex processes of negotiation that occur at the interface between the public and the private, the informal and the formal, the illegal and the legal". These processes are fuelled by constantly evolving 'relations of control and consent, power and authority' (Munro, 1996, cited in Hagmann and Peclard, 2010: 544), and can only be apprehended through adopting a relational concept of power (ibid.: 543), one that encompasses ideas as well as interests, the transnational as well the national and popular as well as elite agency. The remainder of this section draws on this critical literature to show how the new mainstream fails to account for these important aspects of politics, particularly in terms of state capacity and elite commitment. This in turn helps provide the basis for constructing a broad conceptual approach for ESID's research in the next section.

\subsection{Rational-actor bias}

"The central assumption in this framework (political settlements) is that powerful elites are rational actors, and their behavior is driven primarily by pursuit of an inter-related set of economic and power interests" (Parks and Cole, 2010: 8, parentheses added).

The belief that political elites are essentially utility-maximising rational actors pervades recent work on open access orders and political settlements (e.g. Khan, 2010; North et al., 2009; Whitfield and Therkildsen, 2011). This privileging of instrumental rather than value-based forms of rationality constitutes a partial reading of Weber's different forms of social action, and offers at best a narrow reading of elite political behaviour and motivation (see Levi, 2009; Moore, 2003). The tendency here is to ignore aspects of political behaviour and process that cannot be entirely understood in instrumental terms, including the role of ideas and ideology. In such accounts political elites have no motive other than gaining and maintaining power. So, although Parks and Cole (2010: 8) suggest that "These interests are often reinforced and articulated through shared beliefs, ideas, and values", they conclude that "The important point is that changes in elite behavior are driven by changed perceptions of personal (or factional) interest, rather than ideology or national interest".

\footnotetext{
${ }^{17}$ See Cammack (1989) for an earlier argument that critical (in his case Marxist) theory had not only reached some of the same conclusions as the literature on elite bargaining at an earlier stage, but was also able to locate this within a broader frame of analysis that took into account the deeper forces at play here.
} 
Without dismissing the insight that political elite behaviour is strongly shaped by incentives relating to the accumulation of economic resources and political power, to posit a politics without ideas or vision is to offer a reductionist account not only of what drives elites but also of their use of discourse within their strategies of rule and institution-building. As Fukuyama (2011: 10) argues, "Ideas are extremely important to political order; it is the perceived legitimacy of the government that binds populations together and makes them willing to accept its authority". Without legitimacy amongst citizens, political elites find it difficult to promote their political projects (e.g. around nation-building or development), whilst popular expectations and demands help establish the norms by which elites operate and to define what is permissible within the broader 'social contract' between states and citizens. This has become increasingly recognised in studies of state capacity, where "new works on the immaterial components of states also bring the issues of legitimacy and monopoly of knowledge to the forefront when seeking to explain state capacity and its roles in social provision and capitalist transformation" (vom Hau, 2012: 5). Ideas and ideology have also emerged as significant in studies of elite commitment, particularly in the literature on developmental states which often stresses the role played by belief systems and patriotism (Routley, 2012). ${ }^{18}$

Critical approaches accord discursive forms of politics a central role in their understandings of processes of state formation and development, (e.g. Hagmann and Peclard, 2010: 543) and also processes of empowerment and poverty reduction (Webster and Engberg-Pedersen, 2002; Hickey and Bracking, 2005). Here the capacity of the state to rule is understood to be founded as much on the deployment of certain 'repertoires of statehood' by certain groups as on the exercise of more coercive capacities, whereby:

“...states are not only the product and realm of bureaucrats, policies and institutions, but also of imageries, symbols and discourses. Governments exist not only as the result of routinized administrative practices, but also because ordinary people imagine and represent the state in their everyday lives (Gupta, 1995, cited in Hagmann and Peclard, 2010: 543).

How elites choose and deploy their strategies for achieving political and developmental objectives is thus closely informed by and entwined with certain ideas and ideological agendas concerning how politics and development should work. Ideas are understood here not as 'free-floating' entities divorced from the wider political context but rather:

"Ideas are not independent of institutions, structures, and interests. Ideas of a variety of kinds are embedded and implicated in the structures and

\footnotetext{
${ }^{18}$ For Walton (2010: 39-40), "The social contracts that evolved in Mexico under the PRI, in Indonesia under Soeharto, in Thailand until the recent period of turbulence, in India and China over decades, have been consistent with political and economic elites having long-term time horizons. This has typically been backed by nationalist ideology and associated belief systems".
} 
institutions that constitute any political context. Ideas 'make up' or are part of the fabric of the political (and economic and social) world" (Hudson and Leftwich, 2013: 138).

Importantly these ideas circulate at transnational as well as national levels, and matter at both popular and elite levels. The challenge here then is to move beyond the binary established between 'interests' and 'ideas' to explore the ways in which they are intrinsically entwined. As argued by Hay (2010, and paraphrased by Routley, 2012), "interests are always perceived, constructed interests, produced through interactions with the context and influenced by subjective/intersubjective preferences", that is, by the ideas of the actors involved. ${ }^{19}$

\subsection{Elitism}

To the extent that popular agency is considered from a political settlements perspective, it is either through the lens of clientelism or focused on the extent to which elites incorporate groups into ruling coalitions. This may occur because they become too well-organised to ignore or instrumental to the purposes of maintaining a coalition in power. Although this does not entirely rule them out from exerting their agency in meaningful ways, it does reduce them to a subordinate status within political settlements analysis. ${ }^{20}$ The literature has had very little to say regarding the role of identity-based social groupings in forging elite-level agreements, an omission that leaves us (amongst other things) with little understanding of the gendered character of political settlements (Nazneen and Mahmud, 2012).

In an important respect, this is a useful corrective to the overly-optimistic expectations that were heaped on 'civil society' and 'citizenship participation' during much of the 1990s and 2000s. ${ }^{21}$ However, the danger here is that the role of subordinate groups in forging political settlements remains out of view, including their role in shaping the capacity and developmental character of states, despite such a focus being central to alternative political science accounts of state formation and state capacity. For example, Tilly's work on state formation within Europe shows how

\footnotetext{
${ }^{19}$ As discussed below, taking the ideational aspects of politics seriously also introduces a more dynamic perspective (Blyth, 2010) which destabilises some of the more structural sensibilities of the political settlements approach.

20 "Clientelistic inclusion is not all bad, since it does at least bring poorer groups into the political system and provide services. It was an important form of inclusion of immigrants into US cities, for example. But it is typically unequal and asymmetric, embedded in a contemporary form of patron-client relations, and tends to undercut the independent agency of social groups. Of equal importance is the bias against provision of general public goods, whether at the local or regional level." (Walton, 2010: 41).

${ }^{21}$ It also resonates with a broader shift in the literature away from liberal accounts of how democracy and development should emerge and towards a more realistic and politicised understanding of the role played by political struggle, more grounded forms of popular agency in the form of social movements, traditional or neo-traditional forms of organisation (e.g. the reference to traditional and religious leaders who can speak for communities in di John and Putzel's (2009) identification of those elite leaders who may influence or even join those with holding power),productive economic interests, and the importance of forging links between civil and political society (e.g. Corbridge et al., 2005; Fox, 2005; Heller, 2001).
} 
elite settlements reflect the level of organization and engagement in politics of citizens, whilst Slater's (2010) work on the state in South East Asia also emphasises the role of popular uprisings in shaping elite behaviour, in part as a threat. For critical theorists, 'contentious politics' are formative and constitutive of states, with Jessop seeing state power as "a complex, contradictory effect of class (and popular democratic) struggles, mediated through and conditioned by the institutional system of the state" (Jessop, 1990b: 45, cited in 2007: 28; also Cammack, 1989). From a critical perspective on Africa, Hagmann and Peclard argue strongly that,

\begin{abstract}
"Processes of state (de)construction in Africa have been shaped by dynamics of inclusion and exclusion: the question of defining who belongs and who does not belong to the nation (state), who is indigenous and who is foreign, is a crucial object of negotiation (Dorman et al., 2007, cited in Hagmannn and Peclard, 2010: 554). ${ }^{22}$
\end{abstract}

Recent examples from 'proto-developmental states' also reflect the extent to which governing elites incorporate the interests of poor people and regions within their political projects, including cases where the state is taken over by an elite which relies heavily on the poor as a key element of their constituency (e.g. Uganda, Bolivia), or where cases where elites turn to poor groups to bolster their fragile legitimacy (e.g. Zambia, Argentina).

The role of social groups in securing inclusive development becomes more apparent in work that looks beyond economic growth to include the development of broader human capabilities and equity (e.g. Evans, 2010; Sandbrook et al., 2007 and Walton, 2010, as compared to Khan, 2010 and North et al., 2009). For example, Sandbrook et al. (2007) offer a markedly less elitist historical reading of the process through which developmental regimes emerge. Concerned specifically with how social democratic regimes have developed in the global periphery, Sandbrook et al. (2007) identify an earlier role for subordinate groups in accessing and shaping the political settlement. Critical here is the emergence of new configurations of class power as a result of processes of capitalist development, particularly the displacement of landed elites by lower and middle order classes. ${ }^{23}$ This focus can extend beyond class to also encompass concerns with gender. For example, some recent research has

\footnotetext{
${ }^{22}$ State formation involves the categorisation and recognition (or not) of different social groups, often in relation to processes of accumulation that require different social categories to take on particular roles and functions in making capitalism work (Mosse, 2010).

${ }^{23}$ This move beyond intra-elite relations to take greater cognisance of links with broader social groupings helps move the focus onto the broader realm of thinking around state-society relations (e.g. Migdal, 1988). This includes work within the social contract tradition, which for some is a more useful term than 'political settlements', particularly when taking popular agency more seriously and including social as well as economic aspects of development. For example, Walton's (2010) essay on the politics of human development over the long-run also examines the importance of both intra-elite relations and state-society relations as establishing 'political equilibria' or 'social contracts' and comes to much the same conclusion as Khan concerning "...a central channel of causation, from underlying social, economic and political processes through social contracts and institutions to human development outcomes." (Walton, 2010: 38).
} 
drawn attention to the critical role played by women's coalitions in seeking to promote gender equity in developing countries, which demonstrates "how civil society coalitions may draw on and expand their elite networks and exploit political and institutional arrangements to build developmental partnerships" (Hodes et al., 2011). Our research would therefore need to be closely attuned not only to the politics of intra-elite relations but also (a) the development of organisational power amongst more subordinate groups and (b) the specific relationships between these and different elite factions. ${ }^{24}$

\subsection{Methodological nationalism}

Current analyses of political settlements tend to underplay the role of transnational factors in shaping political settlements, ${ }^{25}$ reflecting the wider methodological nationalism that characterises most analyses of governance and development (Unsworth and Moore, 2006). The type of nationalist bourgeoisie that helped forge developmental states in East Asia has been largely displaced by political elites who actively seek to position themselves within transnational flows of power and opportunity. Even those with the commitment to promote development face particular challenges today in seeking to forge political settlements and construct national development strategies in conditions where (for example) banking systems, off-shore tax havens and the arms trade encourage the forms of corruption and extra-state violence that undermine state-building processes. The choices available for developing countries in terms of trade and industrial policy have been closely circumscribed (e.g. Wade, 2003), although the new 'Asian drivers' may be changing this, particularly for countries with new-found natural resource wealth (Mohan, 2012). This is not new: processes of state formation and development in developing countries have long been shaped by external actors, from early mercantilist and colonial encounters onwards. And nor are all transnational forces necessarily detrimental. In the realm of ideas, for example, whilst some dominant ideologies promoted by international development agencies have limited the developmental ambitions of some developing countries, other transnational flows of ideas and epistemic communities have inspired and justifying progressive moves towards social justice.

The point here, though, is to identify conceptual approaches that can help capture the multiple ways in which transnational factors shape the politics of development in poor countries. Critical approaches have long recognised that the nation could no longer be the dominant horizon of state life, from Cox's influential work on international political economy to Jessop's realisation (via Gramsci) that “...it was crucial to analyse how the internal balance of forces was overdetermined by

\footnotetext{
${ }^{24}$ Postcolonial readings of citizenship are also important here in showing how trajectories of citizenship (and state) formation differ markedly between different contexts (e.g. Chatterjee, 2004; Green, 2012).

${ }^{25}$ In the follow-up collection of case-studies to North et al. (2007), this failing has been recognised, and the global has been bolted on as an additional dimension of analysis (North et al., 2013).
} 
international forces and a country's geo-political position and to assess whether and how the latter balance modifies domestic sources" (Jessop, 2007: 114) and to explore how "international relations intertwine with these internal relations of nationstates, creating new, unique and historically concrete combinations" (op. cit.; citing Gramsci, 1971: 182). The pervasive role of supra-national factors in shaping internal political dynamics within African countries is recognised by (again) by Hagmann and Peclard (2010), who show how through a range of processes, including the growing role of China, South-South co-operation and transnational migration, how "...political power in Africa is increasingly 'internationalized' and statehood partly suspended (Schlichte, 2008, cited in Hagmannn and Peclard, 2010: 556). This is also wellcaptured in de Waal's (undated) analysis of African countries as 'rentier political marketplaces', which he argues are characterised by "Integration into the global economy and sovereignty regime on subordinate terms". This closely shapes their politics, including the fact that globalization enables elites to generate enough income (e.g. from aid, natural resources) without extracting revenue from domestic actors and that intermediate elites can access resources through "international institutions, neighbouring states, and illicit markets" without going through the ruler. Globalisation thus fundamentally alters the character of bargaining both between elites and between elites and lower-level groupings in ways that are largely ignored within the development mainstream.

\subsection{The importance of agency and dynamics: 'power in motion'}

"Institutions stabilize the world only because of the constant struggles of agents to impose and contest the ideas that make them possible in the first place (Blyth, 2002). Institutions are the result of agents' attempts to tame uncertainty and create stability, and they are never quite as equilibrating as our theories imagine" (Blyth, 2010: 99).

The tendency of North et al. and Khan to emphasise the significance of history and structure in shaping the development possibilities in poor countries underplays the role of contingency and agency in driving processes of change, and also of change itself. For Poteete, whose work offers a less economic and more holistic approach to political settlements, these forms of economic and historical institutionalism offer an inherently limited perspective on state-building, as their "emphasis on structural constraints and institutional legacies obscures the strategic challenges and opportunities politicians face while competing for power" (2009: 548). As Bates notes in his review of Violence and Social Orders (2010), what goes missing here is the role of the key players who actually make the deals and bargains, an argument taken further by Hudson and Leftwich (2013: 123), who suggest that we need to understand the importance of agency in politics at three levels: individuals, organisations and coalitions. Both Poteete and Leftwich show how coalitions "link social actors to institution building and policy adoption" (Poteete, 2009: 548), and more broadly how a focus on coalitions can grasp the role of both structure and agency, and focuses explicitly on their interplay. For Leftwich (2010: 105), 
"...coalitions are central to the everyday and ordinary politics of all societies and are fundamental for the big global issues of security, state building, economic growth, climate change and political stability". More specifically,

"...political coalitions are required to consolidate and guarantee the 'political settlement' upon which any effective and enduring state depends and which are the hard core of developmental states..." (101-2).

Again, this chimes well with Jessop's reminder that,

"It is not the state that acts; it is always specific sets of politicians and state officials located in specific parts and levels of the state system. It is they who activate the specific powers and state capacities in particular institutions and agencies" (2007: 38).

Such a focus enables research to go beyond the establishment of underlying political settlements and helps make the links between these and the more immediate world of how development strategies are formed and rolled out. ${ }^{26}$ To achieve this we distinguish between the political (or ruling) coalitions that are critical to the operation of political settlements and those policy coalitions which exist to develop and protect certain forms of public action (see next section).

A closer focus on agency in the form of coalitions at different levels also helps to capture the dynamic character of politics and to redress the often static perspective offered within political settlements work. Khan (2010) suggests that political settlements work at different levels over time, but does not explain the linkages between them or how shifts between them might occur. North et al. (2009) suggest that certain doorsteps must be reached before limited access orders can transit towards open access orders, but offer little guidance on the mechanisms through which such transitions occur. North et al. (2009) seem to imagine a fairly benign transition whereby (for example), the fact that elites have created a system of property rights makes it easier for this to be rolled out more fully thereafter on a democratic basis. However, such agreements and the way they shape institutional functioning may actually be very difficult to transform into more universal, let alone pro-poor, forms once they have been inscribed in ways that protect privilege (e.g. see Holston (2008) on land struggles in Brazil and also Agarwal (1994) on the gendered bias within 'original' systems property rights). ${ }^{27}$ Moreover, and given the extent to which a clientelistic political settlement or limited access order is argued to structurally constrain the forms and levels of development that can unfold, it is logical

\footnotetext{
${ }^{26}$ As with the drivers of change approach, there is a danger here that the approach will offer insights at such a deep (even remote) level that the links to the everyday politics of development, and also the world of international development interventions, are difficult to make.

${ }^{27}$ Holston's analysis also suggests that elitist analyses are out of time with current events, whereby "...the worldwide insurgence of democratic citizenship in recent decades has disrupted established formulas of rule and privilege in most societies" (2008: 3).
} 
to assume that opportunities for progress are most likely to occur during instances of dynamic change, where the stability of the settlement is 'unsettled' and increased room for manoeuvre emerges. This is recognised in many accounts of state building, concerning the role of critical junctures, and also recent accounts of pro-poor policy change that see moments of crisis as opening opportunities for reform and progress. Any theory of the politics of development must therefore offer a theory of change rather than of stasis.

\section{Exploring the relational politics of inclusive development: towards a conceptual framework}

The state of conceptual development within the nascent politics and development field, whereby a range of influential theoretical approaches are currently being promoted within both development studies and practice, strongly suggests that what is required at this stage is a period during which competing theories are tested through empirical research and critically evaluated on the power of the insights that they reveal rather than moving directly to the formulation of new approaches. The political settlements approach seems capable of offering powerful insights into the conditions under which developmental forms of state capacity and elite commitment emerge and become sustained, not least because it points directly to the importance of underlying power relations, to politics as struggle and to the links between capitalism and politics. However, the rationale for adopting this approach wholesale within ESID's programme of research has emerged weakened here in light of the argument that the broader realms of political studies, particularly more critical approaches, can capture the core insight into the relational character of politics and power whilst avoiding some of the more reductive tendencies within political settlements analysis. This is important in terms of capturing the role of discursive as well as instrumental material forms of politics, popular as well as elite actors, transnational as well as national factors, and of agency and dynamics as well as structure and equilibrium.

Given that it has also proved difficult to identify a single approach from within critical political theory that can do justice to this broad range of concerns, and also the benefits of retaining a heterodox approach to research within a broad consortium, the preference here is to mobilise insights from critical theory alongside the focus on political settlements within the same programme of research. This involves mapping out a broad conceptual framework which includes a wide range of variables and processes that can be tracked in order to test which offers the greatest traction on the outcomes to be explained, but without (at this stage) over-specifying the precise relationships and mechanisms at play. This form of theory-testing and -refinement can be achieved most persuasively through comparative case study research, which is generally considered the most robust and insightful means of both testing the veracity of particular theories within and across different cases, and also building new theories through examining the interplay of particular variables within and across particular contexts (George and Bennett, 2004). Such an approach, based on a 
carefully selected set of countries, should enable the building of mid-level theoretical generalisations (Kang, 2012) that have relevance to policy actors working across different contexts.

The effort to bring together the insights from both mainstream and critical perspectives is fraught with difficulties, particularly the danger of constructing something of a forced marriage across ontological boundaries. However, there is some evidence that the boundaries between once radically different approaches are more fluid than they once were. Mainstream approaches have increasingly moved into territory once claimed by critical theory, particularly concerning a new appreciation of power relations and the recent move within new institutionalist analyses of elite behaviour to incorporate a stronger focus on the role of ideas as well as incentives (Levi, 2009). ${ }^{28}$ Prime examples of the integrated approach advocated here comes from the recent work on politics of natural resource governance, a field with which ESID is directly concerned. This includes the work of Poteete (2009) on the politics of natural resource governance, which adopts what might be termed an 'extended' political settlements approach that includes a focus on elite ideas as well as interests, and the merging of political theory and critical international political economy approaches achieved within the work of Nem Singh and Bourgouin (2013).

An initial attempt to map out such an approach to understanding the politics of inclusive development is found below in Figure 1. Under this schematic representation of the links between politics and development, the underlying conditions for development are established by formation of particular types of political settlements, a process which occurs in a continuous interplay with institutions, changes in the political economy and also the initial conditions within any given society. This draws on Khan's emphasis on how capitalism shapes political settlements but also Sandbrook et al.'s (2007) findings on the initial conditions that are required for social democracy to emerge (particularly an early insertion within the global political economy and also state formation). This suggests that state capacity and political settlements are mutually constitutive, and that further empirical research is required to establish the precise levels and sequencing issues involved here. What emerges from their interaction sets out the possibilities for inclusive development and can have either progressive or regressive influences (and most likely both).

The diagram seeks to make explicit the ways in which a focus on politics and underlying sets of power relations can be worked through more carefully in terms of the more proximate world of everyday policy-making and implementation. In particular, these underlying conditions are mediated through a set of intermediate

\footnotetext{
${ }^{28}$ See the new generation of thinking on rational choice theory which recognises the importance of taking ideas, and 'cultural' aspects more seriously (Levi, 2009).
} 


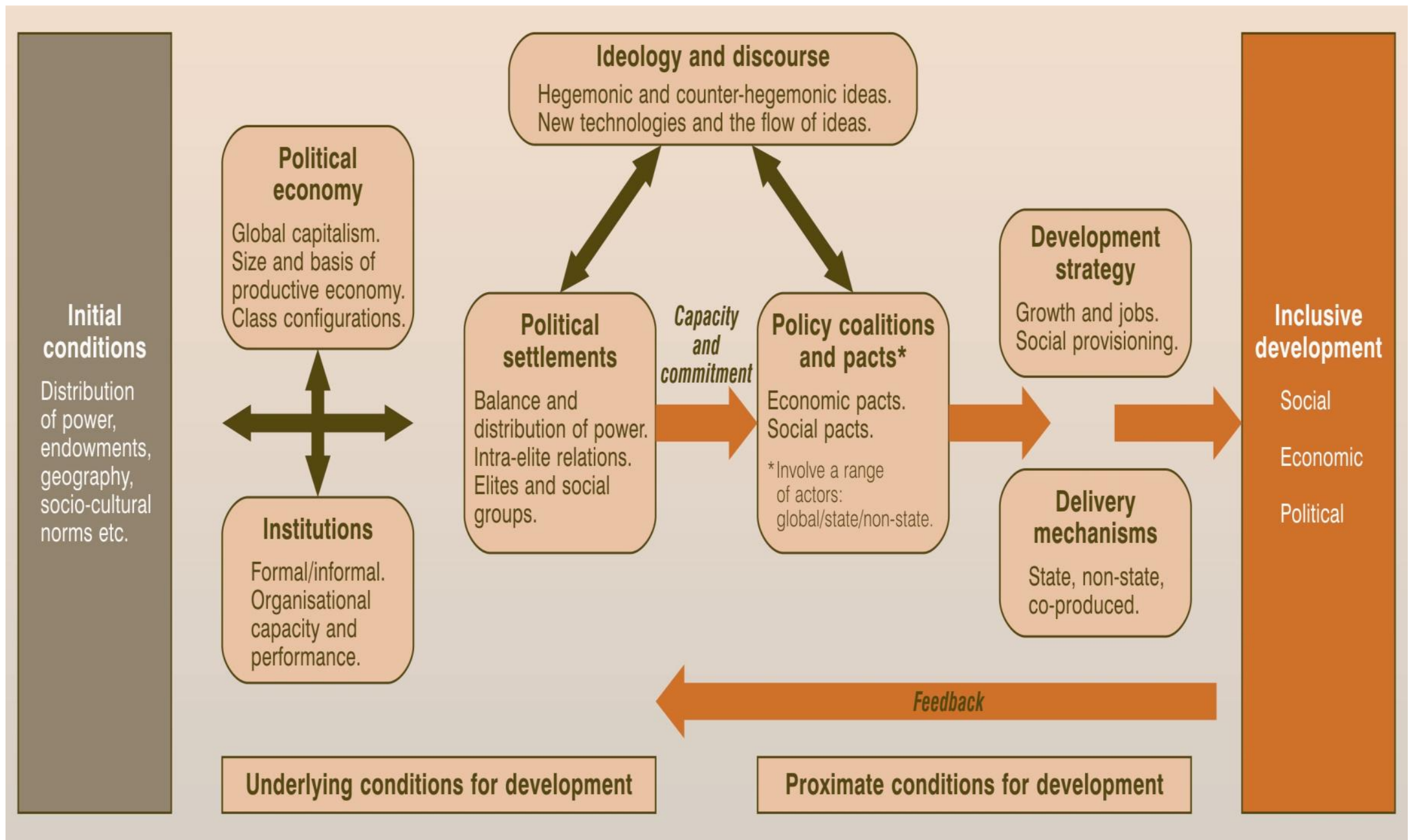


settlements and pacts around the more specific policy agendas that are made by and within coalitions between a range of potential actors (elite and popular; from state, civil society and the private sector; and from transnational as well as national contexts). It is this, in relation to the underlying conditions for development, which establishes the proximate conditions for development in specific contexts. A critical linking factor between the underlying and proximate politics of development concerns the role of agency, particularly in terms of specific relationships between state and non-state actors, and (as suggested above) between coalitions at the level of both politics and policy-making.

Importantly, these coalitions can include a major role for non-state and often transnational actors. Recent work on the co-production of services by state and nonstate actors (Mitlin, 2008) suggests that certain civil society movements have driven the creation of new and developmental forms of policy coalitions by building relationship between local communities, town planners and local politicians. ${ }^{29}$ Transnational actors such as donor agencies may be closely involved in policymaking coalitions, from the role of international financial institutions in establishing macroeconomic strategy through to the promotion of social protection strategies and interventions. Finally, transnational and national forms of capital are often closely entwined in both formal and informal relationships with political elites, in ways that can have different impacts on state capacity and commitment to deliver development according to the characteristics and sectoral location of particular firms.

The influence of transnational factors are emphasised throughout the approach, including the ways in which colonialism helps establish initial conditions, the character and timing of how countries are inserted into the global capitalist political economy, the influence of transnational flows of ideas and also the direct role of international actors in certain policy coalitions. As discussed above, the transnational arena is less and less dominated by traditional development actors, although donors can still be located at several key points of the framework. Most centrally, they may help shape the political economy through their level and type of contribution, may play a role in policy coalitions, and may also contribute to the ideological context within which development policies emerge and are legitimised.

The diagram is also intended to capture the dynamism that characterises the politics of development, including through the identification of critical feedback mechanisms. For example, when governments build roads they are also effectively building state capacity, particularly in terms of its 'infrastructural power'. State legitimacy matters for economic growth (Engelbert, 2002), and the effective delivery of basic services both requires and helps to build political legitimacy. Perhaps most important will be the extent to which development outcomes, particularly in terms of growth and economic

\footnotetext{
${ }^{29}$ More broadly, Fox (2005) notes that "pro-poor reform initiatives are more likely to have broader and deeper institutional impacts if they are accompanied by strategic interactions between policy-makers and civil society counterparts that helps the latter to target and weaken obstacles to change".
} 
transformation, ${ }^{30}$ will reshape class configurations and the size and character of the formal economy in ways that may re-order existing political settlements and introduce new or newly empowered players into coalitions at different levels. ${ }^{31}$

\section{Conclusion}

The burgeoning field of politics and development research has reached a stage of conceptual development, and also influence within policy circles, which demands that influential theoretical propositions are thoroughly and critically tested across a range of contexts, and also across the different domains of development (social, political, economic and environmental). There is a case for approaching this challenge by trying to blend the conceptual insights from (post)institutional economics on power and politics with insights from the broader realms of political theory and of critical approaches in particular, and to work this through comparative case study research before returning to the process of theoretical refinement and development. Broad research consortia such as ESID, which comprise a mixture of different epistemological, disciplinary and methodological perspectives, are grounded in a range of different contexts, and which have a broad focus across the multiple dimensions of development, are well-placed to help engage with this challenge. It is not possible at this stage to predict which approaches, or mixture thereof, will generate the strongest insights into the politics of development, and this may well vary across the broad range of phenomena we propose to investigate. What matters is that we try to leave the field of politics and development not only more empirically rich and theoretically robust than we found it, but also, and in so doing generate a more useful guide to building routes towards social justice.

\footnotetext{
${ }^{30}$ See Sandbrook et al. (2007), also Poteete (2009: 546) "Economic growth generates structural changes, increases the variety of interests in society, and opens up possibilities for new coalitions. Likewise, constraints and opportunities change with regional political and global economic developments".

${ }^{31}$ Other forms of politics will come into play with regards more specific policy agendas, particularly around the politics of implementation, but this diagram seeks to serve a broader purpose here.
} 


\section{References}

Acemoglu, D. and Robinson, J.A. (2006). Economic Origins of Dictatorship and Democracy. New York: Cambridge University Press.

Acemoglu, D. and Robinson, J. (2012). Why Nations Fail: The Origins of Power, Prosperity and Poverty. Crown Business.

Agarwal, B. (1994). A Field of One's Own: Gender and Land Rights in South Asia. Cambridge: Cambridge University Press.

Bates, R.H. (2005). Markets and states in tropical Africa: the political bias of agricultural policies. Berkeley: University of California Press.

Bates, R.H. (2008). When things fell apart. State failure in late-century Africa. Cambridge: Cambridge University Press.

Bates, R. (2010). 'A Review of Douglass C. North, John Joseph Wallis, and Barry R. Weingast's Violence and Social Orders: A Conceptual Framework for Interpreting Recorded Human History', Journal of Economic Literature 48 (September 2010) 3, 752-756

Blyth, M. (2010). 'Ideas, Uncertainty and Evolution'. In D. Beland and Cox, R.H. (eds.) Ideas and Politics in Social Science Research. Oxford: Oxford University Press.

Booth, D. (2011). 'Aid effectiveness: bringing country ownership (and politics) back in', ODI Working Paper 336. www.odi.org.uk

Burton, M. and Higley, J. (2001). 'The Study of Political Elite Transformations'. International Review of Sociology 11(2), 181-199.

Cammack, P. A. (1989). The New Elite Paradigm: A Critical Assessment. Austin, Texas: Institute of Latin American Studies, University of Texas.

Chatterjee, P. (2004). The Politics of the Governed: Reflections on Popular Politics in Most of the World. New York: Columbia University Press.

Corbridge, S., Williams, G., Srivastava, M., and Véron, R. (2005). Seeing the State: Governance and Governmentality in India. Cambridge: Cambridge University Press.

De Waal, A. (undated) The Rentier Political Marketplace and Conflict in the Horn of Africa. A research note.

Di John, J. and Putzel, J. (2009). 'Political Settlements: Issues Paper'. Governance and Social Development Resource Centre, University of Birmingham, June 2009. 
Engelbert, P. (2002). State Legitimacy and Development in Africa. Boulder, CO: Lynne Rienner.

Evans, P. (1995). Embedded autonomy: states and industrial transformation. Princeton: Princeton University Press.

Evans, P. (2010). The Challenge of 21st Century Development: Building CapabilityEnhancing States. New York: United Nations Development Programme.

Fox, J. (2005). 'Empowerment and Institutional Change: Mapping "Virtuous Circles" of State-Society Interaction'. In Alsop, R. (ed.) Power, Rights, and Poverty: Concepts and Connections. Washington, DC: World Bank.

Fukuyama, F. (2011). The Origins of Political Order: From Prehuman Times to the French Revolution. London: Profile Books.

George, A. L. and Bennett, A. (2004). Case Studies and Theory Development in the Social Sciences. Cambridge, MA: MIT Press.

Good, K. (1999). 'The state and extreme poverty in Botswana: the San and destitutes'. Journal of Modern African Studies 37(2), 185-205.

Green, M. (2012). 'Co-producing Ineffective States: Social Knowledge, Social Policy and Social Citizenship in Africa and in development', ESID Working Paper No.14. Manchester: ESID.

Hagmann, T. and Peclard, D. (2010). 'Negotiating Statehood: Dynamics of Power and Domination in Africa'. Development and Change 41(4), 539-562.

Harriss, J., Hunter, J. and Lewis, C. (eds.) (1997). The New Institutional Economics and Third World Development. London: Routledge.

Hay, C. (2010). 'Ideas and the Construction of Interests'. In D. Beland and Cox, R.H. (eds.) Ideas and Politics in Social Science Research. Oxford University Press: Oxford.

Heller, P. (2001). 'Moving the State: The Politics of Democratic Decentralization in Kerala, South Africa, and Porto Alegre'. Politics and Society 29(1), 1-28.

Henley, D.E.F. (2012). 'Agrarian roots of industrial growth: rural development in Southeast Asia and Sub-Saharan Africa'. Development Policy Review 30(1), 25-47.

Hickey, S. (2008). 'The return of politics in development studies (I): Getting lost within the poverty agenda?'. Progress in Development Studies 8(4), 349-58.

Hickey, S. (2009). 'The return of politics in development studies (II): capturing the political?'. Progress in Development Studies 9, 141-152. 
Hickey, S. and Bracking, S. (2005). 'Exploring the politics of poverty reduction: from representation to a politics of justice?'. World Development 33(6), 851-865.

Hickey, S and du Toit, A. (2007). 'Adverse-incorporation, social exclusion and chronic poverty'. CPRC Working Paper 81. Manchester: IDPM. Available at: www.chronicpoverty.org

Higley, J. and Gunther, R. (1992). Elites and Democratic Consolidation in Latin America and Southern Europe. Cambridge: Cambridge University Press.

Hodes, R., Thorpe, J. and Stern, O. (2011). 'Structure and Agency in the Politics of a Women's Rights Coalition in South Africa The Making of the South African Sexual Offences Act, 2007'. Developmental Leadership Program, Research Paper 13. Available at: http://www.dlprog.org/ftp/

Holston, J. (2008). Insurgent Citizenship: Disjunctions of Democracy and Modernity in Brazil. Princeton: Princeton University Press.

Hossain, N. and Moore, M. (2001). 'Arguing For The Poor: Elites And Poverty In Developing Countries'. IDS Working Paper 148. Brighton: IDS.

Houtzager, P. and Moore, M. (eds.) (2003). International Development and the Politics of Inclusion. Ann Arbor: University of Michigan Press.

Hudson, D. and Leftwich, A. (2013). 'From Political Economy to Political Analysis'. Forthcoming working paper for the Developmental Leadership Programme.

IDS (2010). An Upside Down View of Governance. Sussex: IDS.

Jackson, C. (1999). 'Social exclusion and gender: does one size fit all?'. The European Journal of Development Research 11(1), 125-146.

Jessop, B. (1982). The Capitalist State: Marxist Theories and Methods. Oxford: Blackwell.

Jessop, B. (2007). State Power: A Strategic-Relational Approach. Cambridge: Polity Press.

Kelsall, T., and Booth, D. with Cammack, D. and Golooba-Mutebi, F. (2010). Developmental Patrimonialism? Questioning the orthodoxy on political governance and economic progress in Africa'. APPP Working Paper No. 9. London: Africa Power and Politics Programme. Available at: www.institutionsafrica.org.

Khan, M. (2010). 'Political Settlements and the Governance of Growth-Enhancing Institutions'. SOAS, London: Mimeo 
Kurtz, M.J. (2009). 'The Social Foundations of Institutional Order: Reconsidering War and the "Resource Curse" in Third World State Building'. Politics \& Society $37(4), 479-520$.

Knight, J. (1992). Institutions and Social Conflict. Cambridge: Cambridge University Press.

Kohli, A. (2004). State-Directed Development: Political Power and Industrialization in the Global Periphery. Cambridge: Cambridge University Press.

Leftwich, A. (1995). 'Bringing Politics Back In: Towards a Model of the Developmental State'. Journal of Development Studies 31, 400-427.

Leftwich, A. (2004). What is Politics? The Activity and its Study. Cambridge: Polity Press.

Leftwich, A. (2005). 'Politics in Command: Development Studies and the Rediscovery of Social Science'. New Political Economy 10, 573-607.

Leftwich, A. (2008). Developmental states, effective states and poverty reduction: The primacy of politics. Geneva: UNRISD Project on Poverty Reduction and Policy Regimes.

Leftwich, A. (2010). 'Beyond Institutions: Rethinking the Role of Leaders, Elites andf Coalitions in the Industrial Formation of Developmental States and Strategies'. Forum for Development Studies 37(1), 93-111.

Levi, M. (2009). 'Reconsiderations of Rational Choice in Comparative and Historical Analysis'. In Lichbach, M.I. and Zuckerman, A.S. (eds.) Comparative Politics: Rationality, Culture, and Structure. Second edition. Cambridge: Cambridge University Press.

Levy, B. (2012). Working with the Grain: Integrating Governance and Growth in Development Strategies. Draft manuscript, forthcoming.

Lindemann, S. (2008). 'Do inclusive elite bargains matter? A research framework for understanding the causes of civil war in Sub-Saharan Africa'. Crisis States Research Centre, Discussion Paper No. 15. London: London School of Economics

Lund, C. (2006). 'Twilight institutions: Public authority and local politics in Africa'. Development and Change 37(4). 685-705.

Migdal, J.S. (1988). Strong Societies and Weak States: State-Society Relations and State Capabilities in the Third World. Princeton, NJ: Princeton University Press. 
Mitlin, D. (2008). 'With and Beyond the State: Co-Production as a Route to Political Influence, Power and Transformation for Grassroots Organizations'. Environment and Urbanization 20, 339-360.

Mohan, G. (2012). 'China in Africa: Impacts and Prospects for Accountable Development'. ESID Working Paper No.12. Manchester: ESID.

Moore, M., (2003). Arguing the Politics of Inclusion. In Houtzager, P. and Moore, M., op. cit., $260-284$.

Mosse, D. (2010). 'A relational approach to durable poverty, inequality and power'. Journal of Development Studies 46(7), 1156-1178.

Mouffe, C. (1993) The Return of the Political. London/New York: Verso.

Nazneen, S. and S. Mahmud (2012). 'Gendered Politics of Securing Inclusive Development'. ESID Working Paper No. 13. Manchester, UK: University of Manchester

Nelson, J. (2003). Grounds for Alliance? Overlapping Interests of the Poor and Not So Poor. In Houtzager P. and Moore, M., op cit., 119-138.

Nem Singh, J. and Bourgouin, F. (eds.) (2013). Resource Governance and Developmental States in the Global South. Palgrave/Macmillan.

North, D.C., Walliss, J.J. and Weingest, B.R. (2007). 'Limited access orders in the developing world: a new approach to the problems of development' Policy Research Working Paper 4359, Washington DC: World Bank.

North, D.C., Walliss, J.J. and Weingest, B.R. (2009). Violence and Social Orders: A Conceptual Framework for Interpreting Recorded Human History. Cambridge: Cambridge University Press.

North, D.C., Walliss, J.J., Webb, S.B. and Weingest, B.R. (2013). In the Shadow of Violence: Politics, Economics, and the Problems of Development. Cambridge: Cambridge University Press.

Parks, T. and Cole, W. (2010). Political settlements: Implications for International Development Policy and Practice. The Asia Foundation Occasional Paper No. 2.

Post, L. A., Raile, A.N.W. and Raile, E.D. (2010). "Defining Political Will." Politics \& Policy 38(4), 653-676.

Poteete, A. R. (2009). 'Is Development Path Dependent or Political? A Reinterpretation of Mineral-Dependent Development in Botswana'. Journal of Development Studies 45(4), 544-571. 
Rakner, L. (2003). Political and economic liberalisation in Zambia: 1991-2001. Uppsala: Transaction

Rothstein, B. (2002). Cooperation for Social Protection: Explaining variation in Welfare Programs. American Behavioral Scientist 45(5), 901-918.

Routley, L. (2012). Investigating the politics of inclusive development: How do Ideas matter? Discussion Piece for ESID Concepts Workshop, June

Sen, K. and te Velde, D.W. (2009). 'State Business Relations and Economic Growth in Sub-Saharan Africa'. Journal of Development Studies 45, 1267-1283.

Sandbrook, R., Edelman, M., Heller, P. and Teichman, J. (2007). Social Democracy in the Global Periphery. Cambridge: Cambridge University Press.

Slater, D. (2010). Ordering Power: Contentious Politics and Authoritarian Leviathans in Southeast Asia. New York: Cambridge University Press.

Subudubudu, D. with Molutsi, P. (2009). 'Leaders, Elites and Coalitions in the Development of Botswana'. Developmental Leadership Program, Research Paper 02. Available at: http://www.dlprog.org/ftp/

Unsworth, S. and Moore, M. (2006). 'Critique of DFID White Paper on 'Making Government Work for Poor People'. Development Policy Review 24(6), 707715.

van Wyk, J-A. (2009). 'Cadres, Capitalists and Coalitions: The ANC, Business and Development in South Africa'. Developmental Leadership Program, Research Paper 01. Available at: http://www.dlprog.org/ftp/

vom Hau, M. (2012). 'State capacity and inclusive development: new challenges and directions'. ESID Working Paper No.3. Manchester: ESID.

Vu, T. (2007). 'State Formation and the Origins of Developmental States in South Korea and Indonesia'. Studies in Comparative International Development 41(4), 27-56.

Wade, R.H. (2003). 'What Strategies Are Viable for Developing Countries Today? The World Trade Organization and the Shrinking of "Development Space"'. Review of International Political Economy 10, 621-644.

Walton, M. (2010). 'Capitalism, the state, and the underlying drivers of human development'. UNDP: Human Development Reports Research Paper.

Webster, N. and Engberg-Pedersen, L. (eds.) (2002). In the Name of the Poor: Contesting Political Space for Poverty Reduction. London: Zed Books.

Whitfield, L. and Therkildsen, O. (2011). 'What Drives States to Support the Development of Productive Sectors? Strategies ruling elites pursue for 
political survival and their policy implications'. DIIS Working Paper 15. Copenhagen: DIIS.

World Bank (2008). The Growth Report: Strategies for Sustained Growth and Inclusive Development. Washington DC: World Bank 


\section{esid}

identifying routes to social justice

\section{The Effective States and Inclusive Development Research Centre}

The Effective States and Inclusive Development Research Centre (ESID) aims to improve the use of governance research evidence in decision-making. Our key focus is on the role of state effectiveness and elite commitment in achieving inclusive development and social justice.

ESID is a partnership of highly reputed research and policy institutes based in Africa, Asia, Europe and North America. The lead institution is the University of Manchester.

The other founding institutional partners are:

- $\quad$ BRAC Development Institute, BRAC University, Dhaka

- Institute for Economic Growth, Delhi

- Department of Political and Administrative Studies, University of Malawi, Zomba

- $\quad$ Center for Democratic Development, Accra

- $\quad$ Center for International Development, Harvard University, Boston

In addition to its institutional partners, ESID has established a network of leading research collaborators and policy/uptake experts. 